Archivum, LXXI, 2021, pp. 183-211

\title{
A Women Moralising Crusade in the Peninsular War: Bishop Menéndez de Luarca and his Visit to England
}

\author{
Silvia Gregorio Sainz \\ UNIVERSIDAD DE OVIEDO \\ gregoriosilvia@uniovi.es
}

Recibido: $14 / 07 / 2020$

Aceptado: 10/03/2021

\begin{abstract}
:
The Bishop of Santander, Rafael Tomás Menéndez de Luarca, was an enthusiastic representative of the High Catholic Church in Spain between 1784 and 1819. As a declared enemy of France since the Revolution, the Napoleonic troops' advance into Northern Spain forced him to flee into Asturias in November 1808. In May 1809 Menéndez de Luarca managed to escape to Britain, a country he considered 'heretic'. His stay there marked a watershed in the moralising campaign he had started at the beginning of his bishopric. Back in Spain, the progressive loosening of traditional Catholic morals he found in Cádiz had, in his opinion, a negative impact on the Spanish struggle against Napoleon. Menéndez de Luarca's concern for what he had viewed as women's outrageous fashion while in England increased in the Andalusian city. This article aims to analyse the impact of the bishop's English experience on the peculiar campaign he began in Cádiz in 1809 to 'improve' women's conduct. His personal crusade ended up with the publication of a work with an eloquent title, Las desca-
\end{abstract}


misadas o envenustadas modernas españolas (1812). A critical revision of this text includes a brief socio-linguistic analysis of the term 'descamisadas'. This study is completed with an evaluation of the civil authorities' acceptance of the measures suggested by Menéndez de Luarca, together with their social impact.

KEYWORDS: Peninsular War, Bishop Menéndez de Luarca, Women's fashion, 'descamisadas', England, Cádiz.

\section{Una cruzada moralizante hacia las mujeres en la Guerra de la Independencia: El Obispo Menéndez de Luarca y su visita a Inglaterra}

\section{RESUMEN:}

El Obispo de Santander, Rafael Tomás Menéndez de Luarca, fue uno de los más entusiastas representantes del sector conservador de la Iglesia Católica española entre 1784 y 1819. Enemigo de Francia desde su Revolución, tuvo que desplazarse a Asturias en noviembre de 1808 ante el avance de las tropas napoleónicas en el norte peninsular. En mayo de 1809 Menéndez de Luarca consiguió huir a Gran Bretaña, un país que consideraba 'hereje'. Su estancia allí supuso un antes y un después en la campaña moralizadora que había emprendido desde el inicio de su episcopado. De regreso en España, la progresiva relajación de la tradicional moral católica que encontró en Cádiz ponía en riesgo, en su opinión, la lucha contra Napoleón. Su preocupación por la 'inmodesta' moda femenina observada en Inglaterra aumentó en la ciudad andaluza. Este artículo se propone analizar el impacto que la experiencia inglesa del obispo tuvo en la peculiar campaña iniciada en Cádiz en 1809 para 'mejorar' la conducta de las mujeres. Su personal cruzada culminó con la publicación de un trabajo de elocuente título, Las descamisadas o envenustadas modernas españolas (1812). La revisión crítica de este texto incluye un breve análisis sociolingüístico del término 'descamisadas'. El estudio se completa con una evaluación de la acogida por las autoridades civiles de las medidas propuestas por Menéndez de Luarca, junto con su impacto social.

PALABRAS CLAVE: Guerra de la Independencia, Obispo Menéndez de Luarca, moda femenina, 'descamisadas', Inglaterra, Cádiz.

\section{Introduction}

In the late eighteenth century, a socio-cultural change was taking place in Spain which involved an increasing level of 
detachment from the current strict moral standards of the Catholic Church. When Spain declared war on Napoleonic France in 1808, a wide sector of the high ecclesiastical hierarchy understood the conflict as a divine punishment for the Spaniards' progressive loosening in morality. In consequence, the religious and civil authorities started a campaign to redirect public conduct in order to regain God's favour for the Spanish cause against the invading French armies. ${ }^{1}$

This article aims to analyse the particular actions that the Bishop of Santander, Rafael Tomás Menéndez de Luarca, encouraged in Cádiz in 1809 to modify the congregation's doubtful behaviour, especially that of women. The time he spent in the Andalusian city on his return from Britain convinced him of the urgent necessity for national measures intended to do so. The influence of the bishop's sojourn in England on his singular crusade is also briefly analysed. His concerns and suggested course of action were embodied in a tract published with the revealing title, Las descamisadas o envenustadas modernas españolas (1812). This text, together with such an interesting term that goes beyond Spanish women's 'nakedness', is critically analysed. Finally, an examination of the civil authorities' approval for the actions proposed by the bishop, as well as their effect on Spaniards, is carried out.

\section{Menéndez de Luarca: The Origin of an Obsession}

Rafael Tomás Menéndez de Luarca y Queipo de Llano (17431819), third bishop in the Diocese of Santander, a post he kept until he died, was one of the most enthusiastic representatives of the conservative branch and the reactionary ideology in the Spanish Catholic Church. Since the beginning of his episcopal

1 For more information on the involvement of the Spanish Catholic Church in the Peninsular War and on that identification of the conflict with a punishment for that loosening in morality, see J. M. Cuenca Toribio, La Guerra de la Independencia: un conflicto decisivo (1808-1814) (Madrid: Encuentro, 2006); and, E. Martínez Ruiz and M. Gil, La Iglesia Española contra Napoleón. La guerra ideológica (Madrid: Actas, 2010). 
ministry, he uncompromisingly defended the values of sixteenthcentury Spain (Revuelta González, 1982, 2, 674). Menéndez de Luarca's view was that society had the necessary elements to ensure the continuity of the Roman Catholic Church in his country. As the bishop explained in Reglas para la Cofradía o Hermandad y Milicia Cristiana, published in 1788, the Catholic Faith was being threatened at that time by some inner problems that he initially identified with the loosening of orthodox moral standards. Bishop Menéndez de Luarca himself had witnessed that relaxation in his pastoral visits in the region of Cantabria. Therefore, he strongly warned his readership against that tendency in this tract, encouraging at the same time a restoration of the traditional Christian morality for the sake of the country's moral and political welfare.

An example of Menéndez de Luarca's concern to stop social and religious 'bad habits', especially those regarding outfits in church, is found in the pastoral mandates that he sent to the priests in the villages of San Roque de Riomiera and La Penilla (Cantabria) in 1792. The bishop reminded them of the decency with which their congregation should attend church services. Despite his continuous warnings, he also reported that

Entran freqüentemente las mujeres descubiertas o sin mantillas en la cabeza, mal ataviadas, e indecentes de muchos modos, por lo que manda Su Merced a los curas celen sobre el particular y les proiban entrar con sombreros, monteras o de cualquier modo que parezca impropio de la casa del Señor, como lo es también que los hombres estén con redecilla y gorro. (Menéndez de Luarca, in Maruri Villanueva, 1984, 158-159)²

2 My translation: "Women usually come to church uncovered or without mantilla on their heads, badly dressed, and indecent in many ways. For this reason, His Grace orders the priests to observe that particular and forbid churchgoers to enter the temple wearing hats, cloth caps, or any other garment that might seem inappropriate in the Lord's house, as men's hairnets or caps are also forbidden". 
It is interesting to highlight how this relaxation in moral values is, from the very beginning, overtly identified with particular ways of dressing. On this occasion, however, Menéndez de Luarca reprimanded equally women's and men's attitudes in church. In addition, his mandates marked the beginning of a deeply engrained personal concern against Spaniards' growing immoral behaviour. This distress intensified after the storming of the Bastille in 1789, when Religion was also jeopardised with the spread of the French revolutionary ideas in Europe. The prelate tried unsuccessfully to prevent a contagion of such subversive thinking in Santander for its negative consequences on the minds of the inhabitants and, definitely on the altar and throne's current symbiosis.

From 1789 onwards the Bishop of Santander considered France the source of all evil, as reflected in his El Reyno de Dios y su justicia obradora de la paz in 1794. In this work, Menéndez de Luarca described the anarchical state in the neighbouring country due to its sins, consisting of "la lujuria, la codicia, el lujo, la soberbia, la tolerancia religiosa y, en especial, la Falsa Filosofía" (1794, 76-79). ${ }^{3}$ The increased spending on cars, foreign cloth, liquors, etc., showed that the Spanish people were gradually moving away from Christian moderation in imitation of France (52 and 59). Were they to continue with those 'bad habits', he foresaw a dreadful fate for the Spaniards, as described:

Ay! Si, [los franceses] vendrán; y como se establezcan, y como se arraiguen en nuestró País, y aunque no mucho se arraiguen; se arraigará mas presto que ellos, la libertad de conciencia, que vienen á establecer; y España vendrá á ser un bosque inculto de malas costumbres. $(1794,18-19)^{4}$

3 My translation: "Lust, greed, luxury, religious tolerance and, especially, the False Philosophy".

4 My translation: "Oh! Yes, they [the French] will come; and if they settle down, and if they put down roots in our Country, and even if they are not fully established; the freedom of conscience they seek to introduce will root faster than them; and Spain will turn into an uncivilized jungle of bad habits". 
At the time the only solution Menéndez de Luarca could think of was a purifying holy war against the French. Once again, one decade later, in 1806 he insisted in Mentidos arbitrios de felicidad (1812c) that Spaniards should beware of those dangerous ideas coming from France and of their unfavourable effects in Spain. This tract, together with the other two previously published in the early 1790s, shows that the bishop was completely immersed in the supervision and reform of the Spanish people's habits even before the Peninsular War broke out.

Menéndez de Luarca's predictions were sadly confirmed in 1807 when the French troops crossed the Pyrenees. The defence of Religion and its traditional values led him to take active part in the events that unfolded in Spain from 1808 onwards. In particular, he offered the Santander population his wholehearted support after their official declaration of war against Napoleon on May 26. A wide sector of the Spanish episcopate also sided with the patriotic ranks. The singularity of the prelate lies, however, in the way he carried out that defence as 'leader' (he was named president of the provincial Junta [governing board]), 'mastermind' (he encouraged the insurrection in defence of Nation, King and Religion through sermons, pastoral mandates and tracts); and, also as 'insurgent' (he supposedly took active part in the fight) (Revuelta González, 2008, 159-160). In the first months of the conflict, Menéndez de Luarca's actions focused on leading the popular uprising, providing moral, economic and military support and, also, searching for allies. His pastoral activities and that social and moral reform campaign were delayed until, having publicly stated his fierce opposition to Napoleon and France, the bishop was forced to escape first from Santander and some months later from Spain.

\section{A stopover in Britain: An Exceptional Visit}

Napoleon had expressly excluded Bishop Menéndez de Luarca from the Amnesty Decree published on November 12, 1808. The prelate was thus officially declared a traitor of France, 
which meant a sentence to death if arrested (PARES, L1400, 12). ${ }^{5}$ In consequence, when the second French occupation of Santander took place on November 17 that same year, Menéndez de Luarca hastily travelled from the Napoleonic troops' sight into Asturias on board the British frigate Minerva. The Spanish bishop's headlong flight was undoubtedly eased by his regular contact, in an attempt to find support for the Santander uprising, with the British officers on the Northern coast.

John T. Jones, Captain of the Royal Engineers, duly transmitted the bishop's departure from that city to the Secretary of War Robert S. Castlereagh on November 21, $1808 .{ }^{6}$ The British press, specifically The Morning Herald (Durán Porras, 2018, 477) and The Globe, also relayed this news continuing with the papers' tracking of the prelate's actions in the Peninsular War. ${ }^{7}$ From the outset of the conflict, the British readership had surprisingly been offered, through frequent news on the papers, an image of Menéndez de Luarca as the epitome of the Spanish patriot, extolling his intense hatred of Napoleon and militant religiosity. Nothing was said though about his reactionary ideology. This certainly generated a positive view of the Spanish prelate among press readers in Britain as shown by an anonymous poem entitled Lines, an answer to the Archityrant's attack on the character of the Bishop of St. Andero, published in The Morning Post on December 17, 1808. The author of these verses, identified with a 'B.', strongly defended Menéndez de Luarca against Napoleon's attacks (Gregorio Sainz, 2014a, 18). The poem's date of publication suggests that

5 Portal de Archivos Españoles (hereafter, PARES), Decretos sobre España dictados por Napoleón Bonaparte, CONSEJOS L1400, EXP. 12, http://pares.culturaydeporte. gob.es/inicio.html. Mentioned in D. Menéndez de Luarca, 1897, 352-353.

6 John T. Jones to Robert S. Castlereagh, 21 November 1808, The National Archives (hereafter, TNA), War Office (WO) 1/237, ff. 285-288.

7 The Morning Herald (London), 9 December 1808, 3, in Durán Porras, 2008, 477. The Globe (London), 9 December 1808, 2. Online edition in The British Newspaper Archives, https://www.bl.uk/collection-guides/british-newspaper-archive. For more information on the British press tracking of Menéndez de Luarca, see Silvia Gregorio Sainz, "El Obispo de Santander en la prensa británica en 1808: un seguimiento inusual", Spagna Contemporanea, 2014, 7-20. 
the writer referred to the Emperor's accusation of treason against this bishop.

The Minerva arrived off Gijón on November 25, 1808. Once there, Menéndez de Luarca proceeded to the small village of Luanco, where he started a tour through other Asturian and Galician towns (Luarca, Ribadeo, Soto de Luiña, etc.) visiting his relatives and employing himself on pastoral duties. Meanwhile, the prelate was always on the alert for a possible French evacuation of Santander (Gregorio Sainz, 2014b, 523). Unfortunately, this did not happen and his return to Cantabria had to wait. His stay in Asturias was not long either.

On May 19, 1809, as French Generals Michel Ney, François C. Kellerman and Jean-Pierre F. Bonnet's divisions entered that region, the Bishop of Santander boarded The Providentia in Gijón and headed for Britain. That ship, which transported wool to England, seems to have been the only one in the Asturian port at that time. The final destination thus was not Menéndez de Luarca's choice but Fate's. He reached Portsmouth on May 30, as the Gibraltar Chronicle published on July 8 (PARES, 22E, 342). ${ }^{8}$ The mere presence of a Catholic bishop with a highly reactionary ideology in, according to him, a 'heretic' country, together with the allegedly warm welcome given to him, appears to be exceptional. Little is known, however, about the short time he spent there.

In Portsmouth, Menéndez de Luarca was kindly received by the Spanish Commander of the Algeciras, Miguel Gastón. He provided the prelate with all that was necessary given that the latter had fled from Spain in a very precarious situation and did not know the language. According to the bishop's assistant and precentor Francisco Gutiérrez Valdés, Menéndez de Luarca lodged in the English port at an inn and spent his time giving mass in some Catholic chapels, where he was gladly accepted

8 Gibraltar Chronicle, 8 July 1809, PARES, section ESTADO, file 22, E, "Documentación sobre gacetas, diarios y otras publicaciones", f. 342, http://pares. culturay deporte.gob.es/inicio.html. 
by the congregation (D. Menéndez de Luarca, 1897, 383-385). Being in contact with ordinary people and observing their habits, customs and morals, the prelate was no doubt offered the opportunity to form an opinion on the situation in that 'apostate' land.

Soon the bishop also contacted other two Spanish personalities who were in London at that time: Juan Ruiz Apodaca, representative of the Junta Central, and Pedro Cevallos, Minister of State. His fellow countrymen also offered him their unstinting help and influence there (1897, 383-385). Thanks to them, British authorities granted Menéndez de Luarca permission to visit London, which he did on June 10, and some of King George III's ministers (at least, George Canning) agreed to meet him. ${ }^{9}$

The Spanish bishop, however, had no intention of extending his British experience further. As Apodaca had, shortly before the prelate's journey to London, sent him the necessary documents to return to Spain aboard the Algeciras, Menéndez de Luarca went back to Portsmouth after some days in the British capital. Barely a month after his arrival in England, the Bishop of Santander, together with Minister Pedro Cevallos and his family, sailed on board Miguel Gastón's ship towards Cádiz, where he disembarked on July 2, 1809 (PARES, 27B, 170). ${ }^{10}$ In line with the British press' particular interest in Menéndez de Luarca's actions, on August 9 the Statesman published his entry into the Andalusian port. ${ }^{11}$

In summary, in his flight along Northern Spain and England apparently wholly focused on his pastoral office, Menéndez de Luarca was able to see first-hand the state in which Catholic morals

9 Juan Ruiz de Apodaca to George Canning, 10 June 1809, TNA, Foreign Office (FO) 72/84, f. 159.

10 Menéndez de Luarca to the Junta Central, 2 July 1809, PARES, section ESTADO, file 27, B, "Negocios y asuntos religiosos. Arzobispos y obispos españoles", f. 170, http://pares.culturay deporte.gob.es/inicio.html. Mentioned in Menéndez de Luarca, 1897, 388.

11 Statesman (London), 9 August 1809, 2. Online edition in The British Newspaper Archives, https://www.bl.uk/collection-guides/british-newspaper-archive. 
were in those places. The situation was far from ideal on that part of his own country, where there was a clear moral relaxation due to the influence of the newly-arrived French revolutionary ideas on its inhabitants. The lack of a strict control over them by civil and religious authorities also contributed to it. The decay of morality he was observing along the Cantabrian Mountain Range was, although he was expecting it, more noticeable in England. The bishop's British adventure left an impression on him easily seen on his subsequent conduct back in Spain, where he intensified that moralising campaign interrupted by the Peninsular War's outbreak.

\section{A New Babylon: Cádiz (1809)}

Upon his arrival in Cádiz on July 2, 1809, Menéndez de Luarca informed the Junta Central of his presence in the Andalusian city. In that same dispatch he clearly stated his intentions to return to Santander as soon as the situation allowed it, and also to step away from politics and military life. His major concern was then to lead his congregation back to the right Christian moral path. Menéndez de Luarca therefore asked this governing body to relieve him from any possible appointment to a political position in his diocese (PARES, 27B, 170). ${ }^{12}$ Some days later, on July 6, the Junta acceded to the bishop's demand and permitted him to travel back to Northern Spain (PARES, 27B, 171). ${ }^{13}$ Nevertheless, the prelate had to spend some more weeks in Cádiz waiting for the most favourable conditions to do so.

The kind hospitality shown to him there was not enough for Menéndez de Luarca to find the peace he was longing for after his British adventure. The enemy's proximity and the constant threat of a new French occupation, along with the harmful weather conditions to his fragile health (he was 66 years old at that time),

13 The Junta Central to Menéndez de Luarca, 6 July 1809, PARES, section ESTADO, file 27, B, "Negocios y asuntos religiosos. Arzobispos y obispos españoles", f. 171, http://pares.culturaydeporte. gob.es/inicio.html. 
were the main causes of his discomfort. What he found, however, most irritating was to notice in situ the gradual change for worse that was affecting Spanish society. A secularising process, even in the language, heightened in Cádiz, a busy commercial seaport with constant contact with foreign visitors. Analysing the bishop's reactions, this transition also seems to be far more intense than on Northern Spain. Ramón Solís $(2012,110)$ rightly defined the Andalusian city as a frontier between two worlds, as he believed one was bound to disappear and another one was emerging. That city -not yet the 'Cádiz of the Cortes'- represented for Menéndez de Luarca the breakdown of the Ancien Régime structures, the Church and Religion. The revolutionary ideas coming from France were undermining Spain's traditional customs and morality, which he had insistently repeated from 1789 . Interestingly, at no time did the bishop blamed these changes on British influence. In the Andalusian city, Menéndez de Luarca mainly observed this loosening of morals with great distress in the way Spanish women there dressed, or what he considered their 'nakedness' (from an eighteenth-century perspective).

The Bishop of Santander was not the only one to perceive this claimed 'shameful' fashion. A detailed example of that way of Cádiz's women at that time was described by the English Anglican minister Alexander Robert C. Dallas (1791-1869), chaplain to the British army in Spain throughout 1810-1812, ${ }^{14}$ in his Felix Alvarez; or Manners in Spain (1818) under the headline "Female Walking Dress":

The Vandyked basquiña, glittering with bugles, falling many inches short of the ankle which surmounted a foot formed by

14 For more information on Rev. Dallas and his pastoral duty in Spain in the period 1810-1812, see his autobiography (edited by his widow) Incidents in the Life and Ministry of the Rev. Alex. R. C. Dallas [etc.] (London: Nisbet and Co., 1872) and F. Durán López's article “Guerra y pecados de un inglés en Cádiz (1810-1812). Fragmentos de la autobiografía de Alexander Dallas", Cuadernos de Ilustración y Romanticismo, 2016, 22, 435-470. 
nature in the mould of perfect symmetry, and upon which all the art of St. Crispin had been exhausted to display it to advantage, was not put on in vain. Its graceful folds, sustained by the weight of small pieces of lead at the point of each Vandyke, in order, and to the length, fixed by the taste of the wearer, and from which its own lightness and shortness might else have easily subjected it to disorder, were not lost to the eye of the surrounding Señoritos. The intelligent beckon of the head, artfully accompanied by a graceful arrangement of the mantilla to which it seemed necessary, could not escape the object it was intended to attract, nor the more decided language of the fan fail to reach the eye to which it was addressed. (Dallas, 1818, 1, 65-66)

In Cádiz there already appeared to be a general apprehension about that tendency among the most traditional sector of the Catholic Church, even before Bishop Menéndez de Luarca's arrival. At the end of 1808, for example, the superiors of the different religious orders in the Andalusian city, aware of the need to care for the state of morals and decency, agreed that dishonest public behaviour should be prosecuted to regain God's support for the Spanish cause. Otherwise, His wrath would provoke the country's downfall (Carreño, 2006, 321-337; Callahan, 1989, 85; Mestre Sanchís, 1979, 65; Revuelta González, 1979, 11 and 35). As a result, the local Junta published an edict on January 16, 1809, prescribing moderation in the purchase of food and clothes. These measures were especially addressed to women whose "nakedness and excessive decoration" were now strictly forbidden (Solís, 2012, 286). The lack of compliance among locals with these directives seems certain, given the Bishop of Santander's complaints about public female indecency later that year.

Following that reactionary line of thought, Menéndez de Luarca also thought it expedient to extinguish that way of dressing in favour of the whole kingdom. The national moral reform to recover old Christian values he was demanding since 
the late 1790s could not be longer delayed. To this end, on August 6, 1809, the Spanish bishop wrote a new tract entitled Las descamisadas o envenustadas modernas españolas (1812a). Unlike in his 1792 mandates regarding outfits in churches in Cantabria, his argument focuses now exclusively on women. At the same time, it exceeds though the boundaries of those religious buildings and of that region.

The term 'descamisada' was used for the first time in 1768 in Ramón de la Cruz Cano y Olmedilla's farce (comic sketch) El fandango del candil. There seems to have been no more references to this word during the remaining decades of the eighteenth century and in the early 1800s up to its inclusion in Menéndez de Luarca's tract in 1809. And, after that, it would not be in use again until the 1920s in Argentina. Not only did the word refer to the relative female 'nakedness', but it was obviously connected to the male concept 'descamisado', only occasionally employed throughout the eighteenth and nineteenth centuries, with reference to a rebellious nature (Waissben, 2018, 121-122). ${ }^{15}$ And, in this sense, it was used by this Spanish prelate.

For a bishop steadfastly committed to his principles, the Cádiz he observed must have been a very distressing reality. For this reason, as soon as he knew about the French withdrawal from Galicia and Asturias, Menéndez de Luarca decided to abandon that "Babylon", that "valley of Jehoshaphat" (D. Menéndez de Luarca, 1897, 38). In late August he thus sailed on board El Montañés to La Coruña, where he resumed his special crusade against Spain's evils and, especially, female 'immodesty'.

\section{A Particular Crusade against the 'Descamisadas'}

On October 26, 1808, the Junta Central had issued a circular, which the Bishop of Santander knew well, to encourage Spanish people to put forward suggestions for national reform (D. Menéndez de Luarca, 1897, 390-391). Drawing on it, Menéndez

15 This author neither includes any reference to Menéndez de Luarca's tract nor analyses the use of the term during the Peninsular War. 
de Luarca called on that government body on August 28, 1809, from La Coruña first to submit some kind of decree banning women's 'nakedness'. This practice was, as he stated in the appeal, extremely damaging to Religion, the Nation, and, in particular, to Spain's holy war of liberation from the French yoke. Immediate measures should be thus endorsed since the unacceptable fashion he had witnessed in Cádiz was bound to spread, if this had not happened yet, to other regions. Secondly, the bishop requested the Junta to publish Las descamisadas, which he attached to his communication, like an appendix to the future laws on the issue, or failing that, their permission to do so at a personal level to put into force that urgent reform as soon as possible (PARES, 27B, 173). ${ }^{16}$

The most diehard features in Menéndez de Luarca's orthodoxy as the result of his strict religious upbringing openly emerge in Las descamisadas. Continuing with a similar argument to that shown in his previous works, this tract is based on the idea that the war was a divine punishment for the Spanish people's sins. Its author insisted in the introduction to this new text on the urgency for civil authorities, who were blamed for their earlier permissiveness, to pass laws intended to amend what he understood was the most urgent problem, female 'immodesty'. After exhaustively justifying this request on the 1808 Junta Central's notice mentioned above, the prelate explained what this public nuisance consisted in, as follows:

En estas consideraciones (repito) expongo, Señor, como debo, á V. M., que de los muchos, y muy graves crímenes christiano-morales en que yace la Nación, uno es (No sé, si con mas dolor, que horror lo digo) el que, á poco tiempo de haver desembarcado en este Puerto, hallé exaltado tanto ó mas que acababa de llorarlo donde no podía

16 Menéndez de Luarca to the Junta Central, 28 August 1809, PARES, Section ESTADO, file 27, B, "Negocios y asuntos religiosos. Arzobispados y obispados españoles", f. 173, http://pares.culturay deporte.gob.es/inicio.html. Mentioned in Revuelta González, 1982, 676. 
extrañar, le exaltase el humo, que allí rola en vez de la luz, que acá gozamos; y uno es, el que pues aquí se halla tal, no será temeridad pensar, sea semejante en otros Pueblos crecidos del Reyno, y uno, al fin, es el inmodesto; ó deshonesto vestir de las Mugeres, y Familias menudas: Este mal, que, mirado desde sus principios, se halla haver ido creciendo de grado en grado por el descuido, que tubieron en atajarlo, y aún por el fomento, le dieron los primeros Encargados del Bien publico; y este mal, que, haviendo comenzado por sustituir a los antiguos mantos, mantillas, y solitarias (ó como se llamaban los paños destinados á cubrir hombros, espaldas, pechos, y cuellos) otros, y otras de gasas, y telas transparentes, despues otras, y otros escasos, menguados, menguados tanto, que solo cubren mal cubierta la cabeza; finalmente vino a ser un no vestir, con que mujeres de toda clase, y con ellas sus niños, y sus niñas, se presentan en casas, calles, Templos (en los Templos mismos) con el cuello, los hombros, las espaldas, lo mas vecino á los pechos, y con los brazos totalmente desnudos. $(1812 \mathrm{a}, 5)^{17}$

This extract provides the best example of the bishop's writing style and, also, of his personal distress. In addition, the first reference to his stay in Britain, though brief, is made. The relevance of those lines seems clear since there Menéndez de

17 My translation: "Based on these considerations I explain, My Lord, that of all the most serious Christian moral crimes in this Nation, (I do not know if I say this with more pain than horror) the one that, soon after arriving at this port [Cádiz], I found even more exalted than there where, being expected, I have just wept because of it, exalted by the darkness that reels there instead of the light that we enjoy here; and it is the one that found here as such, it will not be reckless to think it is similar in other large villages in the kingdom, and one, at last, is the immodest or dishonest way of dressing in women and children. Looking back this evil has gradually increased due to neglect to stop it, and even to its promotion, by those responsible for the public good. And, this evil had started replacing the traditional veil, mantillas, solitarias (or as the traditional clothing to cover women's shoulders, backs, breasts and necks was known) with others made of crepe or other transparent cloth, and after others so little, so reduced that they hardly cover their head. And, it has ended up being a way of 'no-dressing' by which women from different social classes, together with their children, appear in houses, streets, churches, with necks, shoulders, backs, the nearest parts to their breasts and their arms completely naked". 
Luarca described that country as being laying in darkness in opposition to Spain where light shone (or used to). He employed here the theological light-darkness dualism present in the Old and New Testaments and, mainly, in the Gospel according to Saint John (Trocmé, 1995, 3-13). Obscurity was the result of man's disobedience and distancing from God and Jesus (Rodríguez Rodríguez, 2016, 34), and at the same time incited moral relaxation.

In England, Menéndez de Luarca had unsurprisingly observed a similar fashion (in terms of their 'nakedness' or 'immodesty') among women to the one he was then reporting in Cádiz. The prelate was overwhelmed by a feeling of helplessness as nothing could be done in Britain to prevent it as he lacked any authority there. But seeing that outrageous practice rampant in his own country caused a bigger shock on him, which strengthened his ultra-conservative thinking. Spaniards were also moving away from the strict Christian moral values and, thus, from God's light. These traumatic similarities between Spain, a Catholic country par excellence, and in his opinion an 'unorthodox' Britain might explain the nature of his argument in Las descamisadas and also his insistence for authorities to take action.

The bishop was aware that his suggestions might be regarded as revealing ignorance and bigotry by those who understood the reviled practice as right due to the rooting of the new French revolutionary ideas in them. Menéndez de Luarca reminded them that there had always been Christian laws that limited the improper use of clothing. Those guidelines also stated how the perfect female outfit should be ruled by "La Sobriedad, la Modestia, la Vergüenza, la Santidad" (1812a, 23). ${ }^{18}$ This decency in fashion was, according to the Holy Scriptures, a divine arrangement that compelled all human beings, after the Original Sin, to get dressed so as to cover the corruption of flesh (Genesis, 3:21). The prelate reported that Spanish society, especially its 
women, was losing that quality and therefore contradicted God's will (1812a, 8).

Women were not exclusively responsible for that sin. Developing that initial accusation of permissiveness against public authorities, Menéndez de Luarca also blamed their husbands, priests, judges, and even newspaper editors for allowing this inappropriate practice to take root and spread in Spain. This shared responsibility leads to one of his most controversial reasonings nowadays, because it was justified in women's weak nature. Appealing to Saint Thomas Aquinas, he accused firstly their husbands mostly because "abunda en el hombre mas que en la mujer, la discreción, ó buen uso del Entendimiento" (1812a, 13). For that reason, men were obliged, complying with the sacrament of marriage, to lead their wives righteously. The bishop analysed then the differences between men and women regarding their nature and social function. Consequently, he restricted the latter's role to those of mother and wife. Nevertheless, he granted them an essential characteristic in that union by equalling both sexes in their service to God (13-14). ${ }^{19}$

Secondly, Menéndez de Luarca angrily accused priests of allowing 'las descamisadas' to enter the church. In doing so, they did not fulfil their responsibilities and disregarded the measures established by Saint Charles Borromeo in the sixteenth century as well as by Pope Innocent XI, who forbade those women to receive the sacraments under penalty of excommunication (1812a, 30-31). Although this way of dressing was denounced in all spheres of social life, the prelate seemed appalled by this overtolerance in religious buildings.

Later on, the Bishop of Santander attacked judges, newspaper editors and, finally, society in general due to their passivity in the fight against those sins. They failed to see them as a danger for the Spanish defence against the French as a result of 'False Philosophy' influence (1812a, 37-39). The undergoing social

19 My translation: "Good understanding and discretion abound more in men than in women". 
changes were thus clearly perceptible. This new female fashion was justified in the imitation of the upper classes or even in response to the summer heat. Menéndez de Luarca, however, rejected both alleged reasons and rebutted the latter argument, as can be seen in the following extract, by making reference to the women's 'nakedness' he had observed in England despite the low temperatures there:

Digo también, y certificaré, porque acabo de palparlo, que en Inglaterra era común la desnudez, de que se trata por los meses Mayo, y Junio de este año, en medio de haber tanto frio como por aca en Octubre, y Noviembre; prueba clara de que no el calor del cuerpo, sino el encaloramiento de la imaginacion, sentidos, y apetitos, junto con la frialdad del juicio, son á dictar la miserable escusa, como dictan la miserable moda. $(1812 a, 26)^{20}$

The impact of the bishop's stay in Britain on his subsequent attitude towards women's clothing seems then clear: it helped him comprehend its 'real' causes. It was not merely a question of outfits; the reported practice was thought to have a more subversive background. Menéndez de Luarca understood that the so-called immodesty in women's way of dressing was a sign of pride and arrogance and a symbol of rebellion against husbands, fathers, the Nation and, ultimately, even against God. In his own words,

Se opone primeramente la maldita, y las incosideradas desnudas mujeres, que asi cursan por los pueblos del Reyno, se oponen á lo que queda visto, haber dispuesto Dios, para cubrir la desnudéz

20 My translation: "I also say, and certify, because I have just felt it, that in England this nakedness was common last May and June, when it was as cold as in October or November in Spain. This provides clear evidence that it was not the heat of the body but that of the imagination, the senses and the appetite, together with the coldness of judgement, that issued that miserable excuse, that miserable fashion". 
de nuestros primeros Padres; ... Opónese también a las Santas mencionadas Leyes patrias, que solo consienten tales desnudeces en las publicas rameras; ... se oponen nuestras infelices á su propio, verdadero honor, y con este al de sus maridos, padres y familias; ... se oponen al buen Nombre, al crédito, á la fama, que de honesta, modesta, circunspecta, vimos tuvo, y mereció hasta estos tiempos su Nación, su Patria, su Madre, que como tal deberían honrar, y ayudar á que fuese cada vez mas la que fue ... en todas partes, ó el pio christiano, catholico Reyno por excelencia. $(1812 a, 41-42)^{21}$

The term 'descamisadas' thus does not just refer in this text to female outfits but also to their rebellious attitude towards the established system. In consequence, Menéndez de Luarca thought it necessary to urgently extinguish these new habits. Otherwise, the divine punishment would deservedly lead to the doom of Spain, as he constantly repeated in the tract.

To prevent this from happening, the Bishop of Santander proposed some measures in Las descamisadas. Firstly, he required women to restore Christian modesty in their ways of dressing, especially in churches where they should cover their hair with the traditional veil. This would show loyalty to their husbands and respect to the ecclesiastical hierarchy and, ultimately, to God (1812a, 33 and 55-56). The importance the prelate gave to adequate clothing in those spaces is again illustrated. After that, Menéndez de Luarca renewed his strong initial appeal to the Junta Central to enforce a quick solution. This time he suggested that a legislative bill on outfits be considered in the forthcoming

21 My translation: “The accursed ['nakedness'], together with the thoughtless naked women who frequent the villages in the Kingdom, is against what God was said to have ordered to cover our First Parents' nakedness; ... It also opposes the Holy mentioned national Laws that only allow such nakedness in public whores; ... these poor women go against their own, true virtue and also that of their husbands, fathers and families; ... they defy the good name, credit, reputation for being honest, humble, cautious, their Nation, their Homeland, their Mother, had and deserved until now, and as such it should be respected, and helped to be gradually what it was ..., or the pious Christian, Catholic Kingdom par excellence". 
Cortes, probably in response to the Junta's public consultation in June 1809 on the necessary changes in Spain to be dealt with in that assembly (Revuelta González, 1979, 34-35). Such a project stating the shape and material of clothes, among other aspects, for both men and women would, in the prelate's opinion, put an end to that unchristian fashion. There is something to pay special attention to: men were interestingly once more included in that necessary reform on outfits. The bishop also argued that these laws would help prevent the fickleness of politics that had favoured foreign influence in Spain, particularly French, leading to the situation the country was going through (1812a, 63-65).

The Junta Central did not respond immediately to the request Menéndez de Luarca submitted on August 28. The ordinary system for the processing of those applications might explain the delay until autumn that year. On October 2, 1809, the secretary of that body, Martín de Garay, finally signed the document that refused the bishop's request of a decree forbidding female 'immodesty' (PARES, 27B, 177). ${ }^{22}$ The government's decision was based on the little effect that similar previous laws had had in Spain because, as stated in the resolution, "toda ley que choca con la opinión pública y general de un reyno, es inobservada" (PARES, 27B, 176). ${ }^{23}$ An example of this can be seen on the measures local authorities in Cádiz had unsuccessfully taken with a similar purpose early in 1809 .

On the other hand, the Junta allowed the publication of Las descamisadas, although in Menéndez de Luarca's personal capacity, because that government body considered it was among his religious duties to influence public opinion for

22 Martín de Garay to Pedro Rivero, 23 September 1809; Rivero to Garay, and, Garay to Menéndez de Luarca, 2 October 1809, PARES, Section ESTADO, file 27, B,

"Negocios y asuntos religiosos. Arzobispados y obispados españoles", ff. 173-177, http://pares.culturaydeporte.gob.es/inicio.html.

23 My translation: "Every law that collides with the general public opinion in a Kingdom is unobserved". Rivero to Garay, 2 October 1809, PARES, Section ESTADO, file 27, B, "Negocios y asuntos religiosos", f. 176, http://pares.culturaydeporte.gob. es/inicio.html. 
their improvement. Even so, some remarks were added to the corresponding text. The first referred to its poor stylistic quality, which was described as 'arduous' and 'lowbrow'. Secondly, the bishop was advised not to question judges by accusing them of permissibility. The third, and perhaps the most peculiar remark, required him to withdraw his criticism of the Queen mother María Luisa de Parma's supposed immodesty in her way of dressing (PARES, 27B, 176)..$^{24}$ Menéndez de Luarca's staunch defence of traditional moral values, even if it meant attacking his king's mother, shows his firm convictions in this issue. This last requirement was though the only one the prelate followed when publishing this tract in Santiago de Compostela (Galicia) in 1812.

In addition to Menéndez de Luarca, other religious personalities had also perceived, as stated above, that claimed danger in women's indecent fashion in Spain, especially in Cádiz. Therefore, more initiatives of a similar nature to the bishop's request to the Junta arose in the Andalusian city and, in general, after it. On August 23, 1810, for example, the doctoral canon of the cathedral issued an edict to regulate the female clothing to be employed when attending church services. Likewise, while the Cortes was holding a debate on a national reform of habits and customs, a project on rogations submitted by the Bishop of León was analysed in November 1810. The proposal included a moralising programme that required women to banish their 'nakedness' from the country, together with other sins and public scandals (Solís, 2012, 286, 289 and 475).

The Bishop of Santander's longed-for national measures against female 'nakedness' seemed not to have been implemented still two years after his initial application. Due to what he understood as the Cortes' inaction in March 1811, while in Monte Faro (Galicia), he wrote another tract, Dictamen (1812b). In this new document Menéndez de Luarca continued insisting on the urgent need for government intervention in this regard. He 
suggested at the same time some coercive penalties for offenders, which resembled the very same Inquisition. His position then appeared to be even more extreme than before as can be seen in the following extract:

¿Tan mal vendrá mandar desde luego, que nuestras Españolas modistas vistan, como vistieron las antiguas venerables Matronas, y amables virtuosas Doncellas españolas; y condenar primero en una crecida multa ... , aplicada á las necesidades de la Patria; después á unos exercicios espirituales en la cárcel publica; bajo la dirección de alguna buena Maestra de niñas, que les enseñe la doctrina christiana; después, ó por tercera recaida, á un publico honrado paseo de los en que se dan las once, y reparten plumas en que descanse á las mas benemeritas del asco general (pena leve; aunque mas parezca grave, para las que han ya perdido la vergüenza; y tal vez pena deliciosa para las que, por bien parecer, gustaron presentarse en publico, al poco mas, o menos como aquí se les receta); con el aditamento (esencialísimo) de que los Maridos, Padres, ó Superiores domesticos de las paseandas, y emplumadas lleven del cabestro el Burro, que en la carrera debe servir de carroza triunphal á la inocente ... ? $(1812 b, 66-67)^{25}$

The evident radicalisation in the bishop's ideas and language might be explained by what he considered the civil authorities' total disregard for women's 'improper' outfits, the rapid spread

25 My translation: "Will it be that bad to order, of course, that our modern Spanish women dress as the old matrons and nice, virtuous Spanish maids did; and to sentence them first to a large fine ..., used in the needs of the Nation; after that, to some spiritual exercises in the public prison under the guidance of some good teacher of girls that instruct them in Christian doctrine; after that, or after a third relapse, to a public decent walk like those which last until eleven o'clock, and where feathers are given out for those worthy of public revulsion (light sentence, though it might look severe, for those who have lost all dignity; and maybe a nice sentence for those who, looking good, enjoyed showing themselves in public, more or less as it is suggested here); with the added bonus (most essential) of those walkers' Husbands, Fathers, or superior servants, and [the women] feathered should carry the halter of the donkey, that in the walk should serve to the innocent as a triumphal float ...?". 
of that sinful practice in the kingdom and, mainly, by the gradual secularisation he was perceiving in those government bodies.

From June 1811 onwards, Menéndez de Luarca's situation in Spain changed completely. The work of the Cortes was, according to him, threatening the foundations of Religion, the Church and even the Nation. In consequence, the bishop felt compelled to start a new crusade against the 'liberals' or 'descamisados', who he reported were "tan franceses, cuanto a sus ideas, como los otros" (D. Menéndez de Luarca, 1897, 414). ${ }^{26}$ Therefore, the 'necessary' moral reform had to wait until King Ferdinand VII, 'the Desired', returned to Spain in 1814.

\section{Conclusion}

This article has sought to analyse the particular moralising campaign Menéndez de Luarca carried out from his appointment as Bishop of Santander and, especially, upon his arrival in Cádiz in 1809. Special attention has been paid to his attempts to improve Spanish women's behaviour first in the Andalusian city, where he witnessed first-hand their so-called 'nakedness', and then by extension in the whole country. The impact of the bishop's previous stay in England on his ideology has also been briefly examined. The following conclusions can be drawn:

Firstly, the reform of customs and habits (female 'immodest' clothing included) was a general concern in the late eighteenth century but principally during the Peninsular War. From its outset, the conflict had been identified by the Church as a punishment for Spanish people's sins as a result of a general relaxation in morals. Hence, religious leaders required civil authorities to take measures that extinguished the increasingly lax morality in Spain. Several projects were then suggested to the Nation's government. The singularity of Menéndez de Luarca's campaign lies in its persistence and, mostly, in his thorough reasoning in the tract Las descamisadas to justify the urgent need

26 My translation: "As French, regarding their ideas, as the other ones". 
for actions to modify female conduct. The bishop's concern reflects an ultra-conservative personality that made him try to fight the influence of French revolutionary ideas on the Spanish population. His English experience (or rather, what he found back in Spain in Cádiz) aggravated the prelate's distress since that country was an example of the direction Spanish society was taking. Initially, his crusade focused then on the modern female fashion that, in his opinion, was jeopardising the Ancien Régime structures and somehow the foundations of the Catholic Church. Later on, liberals became his main target.

On the other hand, Menéndez de Luarca's reaction, as well as other bishops and clergymen's complaints, seems out of proportion. The population's gradual detachment from the strict Catholic moral standards gives evidence of the decrease in religiosity that was taking place in Spanish society at that time. Despite that, the description and the explanation of this process might have been exaggerated by the religious leaders. These probably were seeking an immediate and drastic reaction from civil authorities and, in general, from Spaniards as a whole that helped maintain the established system, averting social change.

Finally, this brief analysis has revealed that the suggested measures by Menéndez de Luarca and other men of the cloth to reform the country's immoral behaviour did not have the expected effect among Spanish people. The war was immediately associated with the defence of the Catholic Church. Never was it regarded, however, as a divine punishment for the loosening in morals. The winds of change that the Bishop of Santander had tried to prevent so insistently were already blowing in Spain, as he could observe in Cádiz. The uneasiness he experienced at that time was soon solved. In 1814 Ferdinand VII restored absolutism and thus traditional religion was entirely reinstated. In Menéndez de Luarca the absolutist king found one of his most solid supporters, as history soon after proved. 


\section{Bibliography}

\section{A. Primary Sources}

\section{Manuscripts}

Portal de Archivos Españoles (PARES), http://pares. culturaydeporte.gob.es/inicio.html, Section CONSEJOS, file L1400, EXP. 12; and, ESTADO, file 22, E; 27, B.

The National Archives of the United Kingdom (TNA), Foreign Office (FO) 72/84; and, War Office (WO) 1/237.

\section{Books and Journals}

Dallas, A. R. C. (1818) Felix Alvarez; or Manners in Spain: Containing Descriptive Accounts of Some of the Prominent Events of the Late Peninsular War; and Authentic Anecdotes Illustrative of the Spanish Character; Interspersed with Poetry, Original, and from the Spanish, 2 vols, London, Baldwin, Cradock and Joy.

Menéndez de Luarca, R. T. (1812a) "Las descamisadas o envenustadas modernas españolas, dirigidas para bien general del Reyno Católico a conocer y remediar sus males en una Representación que, hecha a la Suprema Junta Central Gubernativa del mismo Reyno de Sevilla, año de 1809, se publica en este de 1812", in Viva Jesús, Opúsculos Christiano-Patrios que el Obispo de Santander, Don Raphael Thomas Menéndez de Luarca, escribía antes y después de exasperarse los extremados trastornos en que al presente (año de 1811) se hallan las Españas. Y opúsculos que él mismo publica desde el destierro de su Diócesis, en que le tiene la común persecución, cooperando a la justiciera gracia con que, por las entrañas de su misericordia, nos visita el Altísimo para dar la ciencia de salud a su pueblo, y que todos, aprovechándose de la ilustración dispensada a los sentidos en tinieblas, dirijamos nuestros pasos por el camino de la sola verdadera paz, vol. 3, Santiago, Oficina del Exacto Correo y Postillón. Available at: https://bibliotecavirtual.asturias.es/i18n/ consulta/registro. $\mathrm{cmd}$ ? id $=2324$

Menéndez de Luarca, R. T. (1812b) “Dictamen que, asociado de avisos acerca de la reforma moral que necesita las Españas 
para evitar la extrema ruina con que les amenaza, y obtener la summa felicidad que les está ofreciendo la Fuerte-suave Divina Providencia, daba el año de 1811 al Supremo Consejo de Castilla, residente en la Ciudad de Cádiz, y deseaba subiese a las Cortes de la Nación, congregadas allí, el Obispo de Santander, don Raphael Thomas Menéndez de Luarca, preguntado como los otros Obispos del Reyno, sobre lo que debería practicarse para que, durante la imposibilidad de recurrir al cautivo Summo Pontífice Pío VII, se supliese la falta de confirmación de la Santa Sede en las personas presentadas para los Arzobispados y Obispados y o que hubiesen de trasladarse de unas a otras Diócesis", in Viva Jesús. Opúsculos Christiano-Patrios, vol. 3, Santiago, Oficina del Exacto Correo y Postillón.

Menéndez de Luarca, R. T. (1812c) “Mentidos arbitrios de felicidad que, preconizados por el gobierno español a fines del último reynado y desmentidos en sí mismos a la luz de la fe, la razón y la experiencia, al tiempo que sustituidos por otros sanos, santísimos, mediante una Representación dirigida al Trono por mano del primer ministro de Gracia y Justicia un año antes de haber venido a completar nuestro desengaño el padre de la mentira, Napoleón Buonaparte, se representa ahora al público de las Españas para su más acertado gobierno sucesivo", in Viva Jesús. Opúsculos Christiano-Patrios, vol. 2, Santiago, Oficina del Exacto Correo y Postillón.

Menéndez de Luarca, R. T. (1794) El Reyno de Dios y su justicia obradora de la paz de Christo Príncipe de la Paz. Exhortación que el Obispo de Santander hacía a sus diocesanos, y por ellos a todos los españoles, sobre guerrear fuertes en la fe, las guerras del Señor contra sus enemigos los franceses, Santander, Riesgo. Reprint, Santiago: Oficina del Exacto Correo y Postillón, 1812.

Menéndez de Luarca, R. T. (1788) Reglas de la Cofradía o Hermandad y Milicia Cristiana de Cristo Jesús sacrificado sobre el Altar y de la Sagrada Virgen María Madre Dolorosísima que para mayor gloria de estas Magestades, bien espiritual de los vivos y sufragio de los fieles difuntos se establece en la iglesia de Nuestra Señora del Socorro, 
adjutriz de la Parroquial de la ciudad de Santander con aprobación del Supremo Consejo de Castilla y las licencias necesarias, Madrid, Imprenta Real. Reprint, Santander: Riesgo, 1831.

Statesman (London), 9 August 1809, 2. Online edition in The British Newspaper Archives, https://www.bl.uk/collectionguides/british-newspaper-archive.

The Globe (London), 9 December 1808, 2. Online edition in The British Newspaper Archives, https://www.bl.uk/collectionguides/british-newspaper-archive.

\section{B. Secondary Sources}

Alonso, G. (2008) “Del altar una barricada, del santuario una fortaleza: 1808 y la Nación Católica", in Álvarez Barrientos J. (ed.), La Guerra de la Independencia en la cultura española, Madrid, Siglo XXI, 75-103.

Aragón Gómez, J. (2008) "Vida cotidiana en Andalucía durante la Guerra de la Independencia: la verdadera cara de la guerra", Trocadero: Revista de historia moderna y contemporánea, 20, 7-20.

Benítez Martín de Eugenio, J. (2009) “La sociedad española en la época de la Guerra de la Independencia", in Cuenca Toribio, J. M. (coord.), Andalucía en la Guerra de la Independencia (18081814), Córdoba, Universidad de Córdoba, 247-258.

Callahan, W. J. (1989) Iglesia, poder y sociedad en España, 17501874, Madrid, Nerea.

Carreño, M. (2006) “El despertar en la conciencia cívicopolítica popular en los inicios de la España contemporánea: la politización de los sermones en la Guerra de la Independencia 1808-1814", Revista de Educación, 339, 321-337.

Cuenca Toribio, J. M. “El componente religioso en la Guerra de la Independencia", in De Diego, E. (dir.), El comienzo de la Guerra de la Independencia. Congreso Internacional del Bicentenario, vol. 1, Madrid, ACTAS, 48-68.

Durán Porras, E. (2008) Galica, The Times y la Guerra de la Independencia. Henry Crabb Robinson y la corresponsalía de The 
Times en A Coruña (1808-1809), A Coruña, Fundación Pedro Barrié de la Maza.

Esdaile, C. J. (2014) Women in the Peninsular War, United States, Norman- University of Oklahoma Press.

Fernández, E. (2009) Mujeres en la Guerra de la Independencia, Madrid, Sílex.

Gregorio Sainz, S. (2017) “Relaciones hispanobritánicas durante la Guerra de la Independencia (1808-1814). El caso de Cantabria: estudio y repertorio documental", $\mathrm{PhD}$ thesis, Universidad de Oviedo, Oviedo.

Gregorio Sainz, S. (2014a) "El obispo de Santander en la prensa británica en 1808: un seguimiento inusual", Spagna Contemporanea, 46, 7-20.

Gregorio Sainz, S. (2014b) “Los obispos de Santander y Astorga durante la Guerra de la Independencia: ¿anglofilia frente a francofilia?", in García Fuertes, A. (ed.), Mas que una Guerra: Astorga y el noroeste de España en el conflicto peninsular (1808-1814), León, Universidad de León.

Lawrence Tone, J. (1999) "Spanish Women in the Resistance to Napoleon, 1808-1814", in Lorée Enders, V. and Radcliff, P. B. (eds.), Constructing Spanish Womanhood, Albany, State University of New York, 259-282.

Martínez Ruiz, E. and M. Gil (2010) La Iglesia Española contra Napoleón. La guerra ideológica, Madrid, ACTAS.

Maruri Villanueva, R. (1984) Ideología y comportamiento del Obispo Menéndez de Luarca (1784-1819), Santander, Ayuntamiento de Santander and Librería Estvdio.

Menéndez de Luarca, D. (1897) Biografía del Excmo. e Ilmo. Señor D. Rafael Tomás Menéndez de Luarca y Queipo de Llano, tercer obispo de Santander, Oviedo, La Cruz.

Mestre Sanchís, A. (1979) “La Iglesia en la España de los siglos XVII y XVIII", in García Villoslada, R. (ed.), Historia de la Iglesia en España, vol. 4, Madrid, La Editorial Católica.

Revuelta González, M. (2008) "Aspectos religiosos en la Guerra de la Independencia y su repercusión en Palencia", 
Publicaciones de la Institución Tello Téllez de Meneses (PITTM), 79, 159-160. Available at: https://dialnet.unirioja.es/servlet/articulo? codigo $=3053992$.

Revuelta González, M. (1982) "Actitudes opuestas de dos obispos santanderinos ante la Guerra de la Independencia", in Centro de Estudios Montañeses (eds), La Guerra de la Independencia (1808-1814) y su momento histórico, de, vol. 2, Santander, Centro de Estudios Montañeses, 665-686.

Revuelta González, M. (1979) “La Iglesia española ante la crisis del Antiguo Régimen (1803-1833)”, in García Villoslada, R. (dir.), Historia de la Iglesia en España, vol. 5, Madrid, Biblioteca de Autores Cristianos, 3-114.

Rodríguez Rodríguez, J. (2016) "La oscuridad en el Nuevo Testamento", Scripta Fulgentia, 26, 51-52, 29-59. Available at: https://dialnet.unirioja.es/servlet/ articulo?codigo $=6506234$

Solís, R. (2012) El Cádiz de las Cortes: La vida cotidiana en la ciudad durante los años de 1810 a 1813, Madrid, Sílex.

Trocmé, E. (1995) "Light and Darkness in the Fourth Gospel”, Didaskalia, 6, 2, 3-13.

Waissben, D. (2018) "Historia de la palabra descamisado antes del Peronismo", Eadem Utraque Europa 14, 19, 121-122. Available at: https://www.academia.edu /37926414/Historia_de_ la_palabradescamisado_antes_del_peronismo._Primera_parte._ 
